\title{
Mahdollisuuksien rajoissa
}

\section{Neksusanalyysi suomen kielen oppimisesta siivoustyössä}

\author{
Maiju Strömmer
}

\section{Väitöksenalkajaisesitelmä Jyväskylän yliopistossa 15. joulukuuta 2017}

Suomen kielen oppimista ja työllistymistä pidetään keskeisinä tavoitteina aikuisten maahanmuuttajien kotoutumisessa. Yhteiskunnallisessa keskustelussa työllistymiselle ladataan paljon odotuksia: ajatellaan, että työn saamisen jälkeen kotoutuminen on vähintäänkin hyvässä vauhdissa. Työpaikkaa myös pidetään tärkeänä kielenoppimisen areenana (ks. Duff 2007). Suomen kielen oppimista työssä ei ole kuitenkaan vielä paljon tutkittu, ja etenkin suoritustason tehtäviä on tarkasteltu kielentutkimuksessa vain vähän. Väitöskirjassani tutkin, millaisia mahdollisuuksia siivoustyössä on oppia suomea.

Siivous on maahanmuuttajien yleisin työ Suomessa. Yhtäältä se on ammattitaitoa vaativa työ, johon kouluttaudutaan ja joka on osalle elämäntyö. Toisaalta siivousalalla on melko joustavat kielitaito- ja koulutusvaatimukset, mikä mahdollistaa työllistymisen alalle pian Suomeen muuttamisen jälkeen (Trux 2002). Monelle siivoustyö on välivaihe työuralla, niin sanottu sisääntulotyö. Sisääntulotyöt ovat sekä suomalaisille nuorille että vasta maahan muuttaneille ensimmäinen askel työelämään (Forsander 2013: 222-223). Minunkin työurani alkoi kesätöissä siivoojana, kun aloin siivota linja-autoja 15-vuotiaana. Sittemmin etenin samassa yrityksessä matkanjohtajaksi ja konttoriin matkamyyntiin. Opintojen ja koulutuksen myötä olen siirtynyt opetus- ja tutkimustehtäviin.

Myös siivoojina työskentelevistä maahanmuuttajista monella on tavoitteena työllistyä myöhemmin alalle, joka vastaa paremmin heidän ammattitaitoaan (Trux 2002). Usein maahanmuuttajien heikkoa työmarkkina-asemaa selitetään puutteellisella suomen kielen taidolla. Niinpä moni haluaa kehittää kielitaitoaan, jotta työllistyminen laajemmille työmarkkinoille onnistuisi.

Maisterin tutkintoon kuuluvaa tutkielmaa (Partanen 2012) varten haastattelin kansainvälisiä opiskelijoita, jotka opiskelivat sairaanhoitajiksi Suomessa. Haastatteluissa kävi 
ilmi, että heillä kaikilla oli opintojen ohella jokin aivan muu työ, jolla he hankkivat elantonsa Suomessa. Väitöstutkimukseni ensimmäisessä osatutkimuksessa (Partanen 2013) analysoin tätä aineistoa. Keskityin erityisesti siihen, miten haastateltavat kuvasivat mahdollisuuksiaan oppia suomea pesula- ja siivoustyössä. Tätä osatutkimusta voi pitää pilottitutkimuksena tai kartoittamisvaiheena, jossa paikansin tutkimusilmiön kannalta oleellisia kysymyksiä. Näihin teemoihin syvennyin tarkemmin väitöstutkimukseni seuraavissa osatutkimuksissa, joissa analysoin laajempaa etnografista aineistoa.

Tarkastelen kielenoppimista ekologisesta näkökulmasta (van Lier 2004). Tässä työssä keskiössä ovat kielenoppimisen mahdollisuudet, ei siis kielitaidon kehittyminen sinänsä. Toisessa osatutkimuksessa (Strömmer 2016a) analysoin kielenoppimisen tarjoumia. Ne ovat kaksisuuntaisia yhteyksiä kielenoppijan ja hänen sosiaalisen ja fyysisen ympäristönsä välillä (van Lier 200o). Oppiminen edellyttää oppijalta kielellisten resurssien havaitsemista, tulkitsemista ja niiden käyttämistä toimintaan. Toisaalta oppiminen riippuu siitä, millaisia mahdollisuuksia kielelliseen toimintaan ympäristössä on tarjolla.

Kolmannessa osatutkimuksessa (Strömmer 2016b) perehdyin työyhteisön tarjoamaan tukeen. Scaffolding eli oikea-aikainen tuki tarkoittaa sellaista tukea, joka mukautuu oppijan aiemman osaamisen pohjalta ja auttaa häntä suoriutumaan tilanteesta, josta hän ei vielä itsenäisesti suoriutuisi (Wood, Bruner \& Ross 1976). Tutkin kielellisten tukikeinojen lisäksi myös materiaalisia tuen keinoja, koska siivoustyössä kielellinen toiminta yhdistyy kehon liikkeisiin ja välineiden käyttämiseen. Sen vuoksi kehitin käsitteen materiaalinen oikea-aikainen tuki. Tarkoitan sillä ympäröivien objektien hyödyntämistä ja kehollista toimintaa, joilla ymmärtämistä tuetaan.

Neljännessä osatutkimuksessa (Strömmer 2017) perehdyin kielen oppimiseen investoimiseen. Bonny Norton (2000; Norton-Peirce 1995) on kehittänyt tämän käsitteen laajemmaksi vastineeksi motivaation käsitteelle. Investoiminen tarkoittaa sekä sitä, miten yksilö itse panostaa oppimiseen, että sitä, miten oppimisen konteksteissa kuten työpaikalla siihen panostetaan (Norton 2000; Darvin \& Norton 2015). Uutta kieltä opettelemalla yksilöt tavoittelevat esimerkiksi parempaa työpaikkaa tai tietyn yhteisön jäsenyyttä. Käsite eroaa motivaation käsitteestä, koska myös oppijan positioiminen vaikuttaa siihen, mihin oppimisen resursseihin hänellä on pääsy. Vaikka oppijan motivaatio olisi vahva, hän saattaa kohdata syrjiviä käytänteitä tai hänen pääsyään oppimistilanteisiin saatetaan rajoittaa.

Keräsin tutkimuksen aineiston etnografisella otteella kahdessa siivouskohteessa. Ensimmäinen niistä on tapahtumakeskus, johon siivouspalvelut ostetaan eräältä suurelta siivousyritykseltä. Kenttätutkimukseni aikaan tiloja siivosi Ugandasta Suomeen muuttanut mies, peitenimeltään Kifibin. Hän oli tullut Suomeen opiskelemaan ja valmistunut luonnontieteiden maisteriksi, mutta ei ollut saanut muuta kuin siivoustyötä. Tapahtumakeskuksessa hän oli ainoa siivooja ja työskenteli enimmäkseen tyhjissä tiloissa.

Tutkimukseeni osallistui myös sellainen asiantuntijaorganisaatio, joka ei ostanut siivouspalveluja ulkopuoliselta yritykseltä vaan palkkasi itse oman siivoushenkilöstönsä. Siellä seurasin viiden hengen siivoustiimiä, johon kuului kolme suomalaista naista, Thaimaasta kotoisin oleva nainen, peitenimeltään Mae Noi, ja Gambiasta Suomeen muuttanut mies, peitenimeltään Omar. He olivat molemmat muuttaneet Suomeen avioliiton myötä, ja heillä on aiempaa työkokemusta eri tehtävistä: Omar on työskennellyt 
ruuanjakelussa, laivalla ja tehtaalla ja Mae Noi hierojana, kokkina ja tarjoilijana. Heidän siivoustiimissään kaikilla oli oma siivousalue, mutta he kokoontuivat yhteen tauoilla ja käyttivät suomea työkielenä.

Sovellan neksusanalyysia (Scollon \& Scollon 2004) tutkimuksen teoreettismetodologisena viitekehyksenä. Neksus tarkoittaa verkostoa tai yhteyttä. Neksusanalyysin mukaan kielellinen toiminta ketjuuntuu, risteää ja linkittyy aiempien vuorovaikutustilanteiden ja yhteiskunnassa vallalla olevien diskurssien kanssa. Tutkimuksessani tarkastelen niitä sosiaalisia käytänteitä, jotka vaikuttavat suomen kielen oppimiseen työssä neksusanalyysin keskeisten elementtien eli vuorovaikutusjärjestyksen, toimijoiden elämänhistorian ja diskurssien näkökulmista.

Vuorovaikutusjärjestyksen analysoiminen on keskeistä, koska vuorovaikutustilanteet vaikuttavat keskeisesti kielenoppimisen mahdollisuuksiin. Käsite on alun perin Goffmanin (1983), jonka mukaan erilaisia tilanteita ohjaavat tietyt historiallisesti rakentuneet sosiaaliset normit ja odotukset. Olen analysoinut väitöskirjassani tarkemmin ohjaustilanteita, työn organisoimista ja lomakkeiden täyttämistä, jotka ovat siivoustyössä oleellisia viestintätilanteita.

Toimijoiden elämänhistorialla viitataan siihen, kuinka yksilöt ovat sisäistäneet erilaisia toimintatapoja ja käytänteitä elämänsä kuluessa (Scollon \& Scollon 2004: 13). Olen ottanut tutkimuksessani huomioon osallistujien aiemman työkokemuksen, koulutustaustan ja kokemukset suomen kielen oppimisesta. Nämä kokemukset vaikuttavat myös siihen, millaisia työhön ja kielenoppimiseen liittyviä tulevaisuudentavoitteita heillä on.

Kolmantena elementtinä ovat diskurssit eli käytetty kieli ja tekstit työpaikalla (Scollon \& Scollon 2004: 14). Olen tarkastellut myös sellaisia yleisiä käsityksiä maahanmuuttajien kielitaidosta ja työllistymisestä, jotka vaikuttavat osallistujien toiminnan taustalla. Neksusanalyysissa painotetaan, että kielenkäyttö reaalistuu aina tietyssä fyysisessä paikassa. Väitöskirjassani olen analysoinut, kuinka kielenkäyttö rakentuu eri työtiloissa, koska siivoojan työ on liikkuvaa.

Tutkimukseni ensimmäinen päätulos on, että mahdollisuudet oppia suomea siivoustyössä ovat vähäiset. Koska siivoaminen on itsenäistä ja rutiininomaista työtä, voi vuorovaikutuksen määrä työpäivinä olla pieni. Erityisesti siivouspalvelujen yksityistäminen aiheuttaa rakenteellisia esteitä kielenoppimiselle. Kun organisaatiot ostavat siivouspalvelunsa yksityisiltä siivousfirmoilta, siivooja ei ole osa sitä työyhteisöä, jonka tiloissa työskentelee. Siivousalalla on kova hintakilpailu, mistä johtuen siivouskohteet usein vaihtuvat sopimusten päätyttyä. Siivoojat myös tyypillisesti kiertävät kohteesta toiseen eivätkä välttämättä näe työkavereitaan työpäivien aikana. Työyhteisöön integroituminen on siis haastavaa, eikä pysyviä vuorovaikutussuhteita pääse syntymään. Siivousorganisaatiot ovat usein hyvin monikielisiä, ja suomen lisäksi etenkin englannin kielen asema on vahva. Pelkän englannin käyttäminen työkielenä ei tietenkään edistä suomen kielen oppimista.

Parhaassa tapauksessa siivoustyössä voi kuitenkin tarjoutua mahdollisuuksia suomen kielen oppimiselle. Etenkin se tutkimukseen osallistunut organisaatio, joka palkkasi omat siivoojansa, oli tästä hyvä esimerkki. Siellä siivoustiimi oli päivittäin tekemisissä keskenään, ja siivoojat keskustelivat myös toimistotyöntekijöiden kanssa. Kielellisiä tilanteita siivoustyössä ovat palaverit, perehdyttäminen, ohjeistaminen ja työn orga- 
nisoiminen. Lisäksi työympäristön tekstit voivat tarjota mahdollisuuksia oppia kieltä. Työkoneiden ohjeet ja sähköiset lomakkeet eivät kuitenkaan aina avaudu oppijalle ilman työyhteisön tukea.

Toinen päätulos on, että kielenoppimisen mahdollisuudet riippuvat pitkälti työyhteisöstä. Työyhteisö voi tukea suomen kielen oppimista monin tavoin. Kielellisiä keinoja ovat toistaminen, yksinkertaistaminen, selkeä puhe ja toisin sanoin sanominen. Siivous on konkreettista työtä, ja havaintojeni mukaan ohjeistamisessa käytetäänkin paljon havainnollistamista. Siivouskohteet, työvälineet ja tehtävät voidaan näyttää konkreettisesti. Kielenoppimista edistää, jos havainnollistamista käytetään samansuuntaisesti ja synkronisesti kielellisen tuen kanssa. Tämä saattaa kuitenkin tarkoittaa sitä, että siivoustyössä käytettävä kieli kohdistuu konkreettisiin, toistuviin toimiin eikä etenkään edistyneelle oppijalle tarjoudu mahdollisuuksia kielitaidon kehittämiseen. Oikea-aikaisen tuen antaminen on tasapainottelua: tuen määrää tulisi vähentää mahdollisuuksien mukaan, jotta työntekijä pääsee itsenäistymään.

Kolmas päätulos on, että mielekkäät urapolut ja oppijan myönteinen positioiminen motivoivat investoimaan kielenoppimiseen työssä. Ammatillisen kielitaidon kehittäminen on tarkoituksenmukaista silloin, kun yksilön aiempi työkokemus, koulutus ja urasuunnitelmat ovat linjassa siivoustyön tekemisen kanssa. Tämän tutkimuksen perusteella ammatillisten sisältöjen ja kielen opiskelun integroiminen esimerkiksi oppisopimuskoulutuksessa on mielekästä. Kielenoppimiseen panostaminen tuntuu tärkeältä, jos kielitaidon kehittäminen auttaa etenemään uralla.

Kielenoppimiseen investoimista rajoittaa näköalattomuus, jos tarkoitustenmukaiset urapolut puuttuvat. Etenkin länsimaiden ulkopuolelta tulevien koulutettujen maahanmuuttajien on haastavaa löytää oman alan työtä Suomessa, ja heistä moni työskentelee suoritustason työssä niin sanotuilla maahanmuuttaja-aloilla (Kyhä 2012; Forsander 2013). Tällöin ammatillisen kielitaidon kehittäminen ei onnistu. Investoimisen rajoitteena on myös se, että ulkoistetuissa siivouspalveluissa siivoojat positioidaan työyhteisön ulkoreunoille, joten he eivät pysty osallistumaan täysivaltaisesti työpaikkansa sosiaaliseen toimintaan.

Tutkimukseni tuloksia voidaan hyödyntää maahanmuuttajien suomen kielen opetuksessa ja ammatillisessa koulutuksessa. Tulokset tarjoavat myös monikielisille työyhteisöille hyviä käytänteitä kielenoppimisen tukemiseen. Kielelliset käytänteet eivät kuitenkaan muutu ilman kielitietoisuuden vahvistamista. Kouluissa painotetaan nykyään kielitietoista pedagogiikkaa, ja samat periaatteet olisivat hyödyksi myös työelämässä. Valtaväestön jäseniä voisi vastuuttaa tukemaan oppimisprosessia nykyistä enemmän. Kaikki me olemme osa kieliyhteisöä, joka voi tarjota mahdollisuuksia oppia suomea. Tutkimukseni perusteella joustava monikielisyys on työkonteksteissa hyödyllistä. Eri kieliä voi siis käyttää ymmärtämisen varmistamiseen, ja suomen kielen määrää on hyvä lisätä ajan myötä.

Työ- ja elinkeinoministeriön (2017) tavoitteena on vauhdittaa aikuisten maahanmuuttajien työllistymistä, ja kotoutumiskoulutukselle on esitetty vaihtoehtoisia koulutusmalleja, joihin voi sisältyä aiempaa enemmän työssäoppimista. Tämän tutkimuksen valossa ei voida olettaa, että työssä kuin työssä ikään kuin automaattisesti oppisi suomea. Vaarana on, että kielikoulutuksen määrän vähentäminen nopean työllistämisen vuoksi 
heikentää kielenoppimisen mahdollisuuksia. Jos siis kielikoulutuksen määrää vähennetään muutamaan tuntiin viikossa ja työssäoppimisen määrää lisätään, on syytä varmistaa, että suomenoppija saa tarvitsemaansa tukea ja pääsee osalliseksi työyhteisön vuorovaikutustilanteisiin. Parasta olisi, jos kieltä voisi oppia sekä kielikoulutuksessa että työssä.

Myös merkityksellisten työurien tarjoamiseen tulisi kiinnittää huomiota, koska mielekkäät työllistymisnäkymät motivoivat kehittämään kielitaitoa tavoitesuuntautuneesti. Maahanmuuttajilla ei aina ole tarpeeksi tietoa niistä ehdoista ja mahdollisuuksista, joita Suomessa on työllistymiselle. Kotoutumisen tavoitteena on, että maahanmuuttaja kokee olevansa yhteiskunnan täysivaltainen jäsen, jolla on uudessa kotimaassa tarvittavia tietoja ja taitoja. Tutkimukseni perusteella ei voi katsoa, että työllistyminen tai suomen kielen oppiminenkaan takaisivat onnistuneen kotoutumisen.

Siivoustyö oli minulle mielekäs kesätyö. Tutkimukseeni osallistunut Kifibin sen sijaan on työskennellyt siivoojana Suomessa nyt jo seitsemän vuoden ajan. Hän tuli Suomeen, koska halusi kouluttautua lisää, ja opiskeli täällä maisterin tutkinnon. Hänen unelmanaan on suorittaa tohtorin tutkinto ja työllistyä sen jälkeen opettajaksi ja tutkijaksi yliopistoon. Kun kerroin Kifibinille, että väittelen, hän onnitteli minua, harmitteli, ettei pääse työnsä vuoksi paikalle, ja pyysi: "Ole kiltti, lähetä kuvia."

\section{Lähteet}

DARVin, Ron - Norton, Bonny 2015: Identity and a model of investment in applied linguistics. - Annual Review of Applied Linguistics 35 s. 36-56. https://doi.org/10.1017/ So267190514000191.

Duff, PAtricia 2007: Second language socialization as sociocultural theory. Insights and issues. - Language Teaching 40 s. 309-319. https://doi.org/10.1017/So261444807004508.

Forsander, AnniKa 2013: Maahanmuuttajien sijoittuminen työelämään. - Tuomas Martikainen, Pasi Saukkonen \& Minna Säävälä (toim.), Muuttajat. Kansainvälinen muuttoliike ja suomalainen yhteiskunta s. 220-244. Helsinki: Gaudeamus.

Goffman, Erving 1983: The interaction order. - American Sociological Review 48 s. 1-17. https://doi.org/10.2307/2095141.

Kyнӓ, Henna 2012: Korkeakoulututkinto ei takaa maahanmuuttajille töitä. - Siirtolaisuus Migration 39 (1) s. 18-22.

LiER, LEO VAN 2000: From input to affordance. Social-interactive learning from an ecological perspective. - James Lantolf (toim.), Sociocultural theory and second language learning s. 245-26o. Oxford: Oxford University Press.

2004: The ecology and semiotics of language learning. Dordrecht: Kluwer Academic Publishers.

Norton, Bonny 2000: Identity and language learning. Gender, ethnicity and educational change. Essex: Longman.

Norton-Peirce, Bonny 1995: Social identity, investment, and language learning. - TESOL Quarterly 29 s. 9-31. https://doi.org/10.2307/3587803.

Partanen, Maiju 2012: Matkalla sairaalaan. Maahanmuuttajien käsityksiä suomen kielen oppimisesta sisääntuloammatissa. Suomen kielen pro gradu -tutkielma. Jyväskylän yliopisto. http://urn.fi/URN:NBN:fi:jyu-201206271974. 
- 2013: Suomen kielen oppimisen mahdollisuudet ja työyhteisön tuki puhdistuspalvelualalla. Afrikkalaisten maahanmuuttajien käsityksiä ja kokemuksia. - Tiina Keisanen, Elise Kärkkäinen, Mirka Rauniomaa, Pauliina Siitonen \& Maarit Siromaa (toim.), Osallistumisen multimodaaliset diskurssit s. 55-76. Suomen soveltavan kielitieteen yhdistyksen julkaisuja 71. Jyväskylä: Suomen soveltavan kielitieteen yhdistys AFinLA.

Scollon, Ron - Scollon, Suzie Wong 2004: Nexus analysis. Discourse and the emerging internet. London: Routledge.

Strömmer, MAIJU 2016a: Affordances and constraints. Second language learning in cleaning work. - Multilingua. Journal of Cross-Cultural and Interlanguage Communication 35 s. 697-721. https://doi.org/10.1515/multi-2014-0113.

2016b: Material scaffolding. Supporting the comprehension of migrant cleaners at work. - European Journal of Applied Linguistics 4 s. 239-275. https://doi.org/10.1515/eujal-2015-0039.

2017: Work-related language learning trajectories of migrant cleaners in Finland. - Apples. Journal of Applied Language Studies 11 (4) s. 137-16o. https://doi.org/10.17011/apples/ urn.201712214863.

Trux, MarJa-Lirsa 2002: Diversity under the northern star. - Annika Forsander (toim.), Immigration and economy in the globalization process. The case of Finland s. 175-225. Helsinki: Sitra.

Työ- ja elinkeinoministeriö 2017: Maahanmuuttajien koulutuspolkujen nopeuttaminen ja joustavat siirtymät -työryhmän loppuraportti ja toimenpide-esitykset. Työ- ja elinkeinoministeriön julkaisuja 36/2017. Helsinki: Työ- ja elinkeinoministeriö. http://urn. fi/URN:ISBN:978-952-327-238-5.

Wood, David - Bruner, Jerome - Ross, Gail 1976: The role of tutoring in problem solving. - Journal of Child Psychology and Psychiatry 17 s. 89-10o. https://doi. org/10.1111/j.1469-7610.1976.tboo381.x.

Maiju Strömmer: Mahdollisuuksien rajoissa. Neksusanalyysi suomen kielen oppimisesta siivoustyössä. Jyväskylä Studies in Humanities 336. Jyväskylä: Jyväskylän yliopisto 2017. Väitöskirja on luettavissa osoitteessa http://urn.fi/URN:ISBN:978-951-39-7265-3.

Kirjoittajan yhteystiedot: etunimi.sukunimi@jyu.fi 